\author{
Dejan B. Momčilović \\ Research Assistant \\ Institute for material testing \\ Belgrade \\ Aleksandar Subić \\ Professor \\ RMIT University \\ Mechanical and Manufacturing Engineering \\ School of Aerospace, Melbourne \\ Australia \\ Ivana D. Atanasovska \\ Assistant Professor \\ Institute Kirilo Savič \\ Belgrade \\ Radivoje Mitrović \\ Professor \\ University of Belgrade \\ Faculty of Mechanical Engineering
}

\section{Combined Load Simulation vs Component Loads Simulation in Machine Design - a Case Study}

At a present level af technology, almost all machine parts are subjected to combined loads in real working condition. The aim of research described in this paper is to highlight the importance of combined load simulation for the calculation of machine parts load capacity. This research is inspired by one failure case study of hydro turbine shaft. The shaft with flange and high ratio of shaft/flange diameter is the subject of excessive calculation in order to find the cause of failure.

The classic analytical calculation of this shaft uses the Peterson's elastic stress concentration factor and calculates stress concentration factors and maximum stresses for different stress components of combined load and then calculate analytical values of total stress by the hypothesis of maximum normal stress. On the other hand, presented Finite Element Analysis simulates shaft stress state under real conditions of complex load by simultaneously applying all load components (bending, torsion and tension). Bboth of the calculations are performed for few different radii in shaft-flange sections.

The results are presented by comparative diagrams for obtained values of total stresses and stress concentration factors. The analysis of these diagrams leads to conclusion that the use of Peterson's stress concentration factors and standard analytical techniques for total stress calculation has to be replaced with modern calculation techniques that provide a more accurate, easier-to-handle solution.

Keywords: stress concentration factor, Finite Element Analysis, shaft.

\section{INTRODUCTION}

The comprehensive and accurate stress state calculations in the process of machine elements design is one of the main influencing factors affecting the lifetime, operational reliability and energy efficiency of machine elements, [1], [2]. This is very important for rotating parts of mechanical systems and machines with non-standard design. Unexpected interruption in regular operation, transmission of rotating movement, is very often caused by the occurrence of cracks on stress concentration sites on shafts and rotors. Such events almost always have catastrophic consequences for particular parts or complete mechanical systems and these events are very costly.

This is important if we know that until today, choosing the right way of predicting a component's fatigue life was a matter of believing, rather than unified viewpoint based on engineering practice. Particularly in the high-cycle-fatigue (HCF) regime, there is mostly a factor of two and more between the predicted and the actual fatigue life. Even the question about the existence of a fatigue limit already raised in 1860 by August

Received: December 2013, Accepted: January 2014

Correspondence to: Prof Radivoje Mitrović

Faculty of Mechanical Engineering,

Kraljice Marije 16, 11120 Belgrade 35, Serbia

E-mail: rmitrovic@mas.bg.ac.rs

doi:10.5937/fmet1401048M

(C) Faculty of Mechanical Engineering, Belgrade. All rights reserved
Wöhler has not been not finally answered. All above mentioned actually emphasize the significance of strengthening the very basics of knowledge in mechanical engineering [3].

Thus, to establish the adequate methodology for monitoring and prevention of rotating parts failures it is of great importance to define the optimal working conditions and load capacities of particular machine elements. [4] and [5]. A detailed survey of basic problems related to crack occurrence in stress concentration factors are presented in references [6] and [7]. However, the majority of research in structural integrity is focused on crack detections and crack growth rate calculation, which leaves classic approach, the calculation and use of stress concentration factors, uncovered.

The major aim of this paper is to fill this gap and add confirmation of engineering philosophy explained in this introduction.

\section{STRESSES AND STRESS CONCENTRATION FACTORS}

The elementary stress formulae used in the design of structural parts are based on the parts or members having a constant section or a section with gradual change of contour. Such conditions, however, are hardly ever attained throughout the highly stressed region of actual machine parts or structural members. The 
presence of shoulders, grooves, holes, keyways, threads, etc., results in modifications of the simple stress distributions so that localized high stresses occur. This localization of high stress is known as stress concentration, measured by the stress concentration factor.

The long-held and common engineering practice uses standard analytical methods and Peterson's stress concentration factors (SCF) for calculation of shoulder filleted shafts, [8]. Peterson's stress concentration factors are determined for shafts with standard dimensions. Peterson's original equations for shoulderfillet stress-concentration factors (SCF) were actually rough engineering estimates. The analytical tools available when Peterson compiled his stressconcentration factors forced him to base his calculations for shoulder fillets on solutions for similar geometries, instead of directly calculating the stress state. This solution is only applicable for limited ranges of shaft dimensions and takes the form of separate graphs for the three loading modes: bending, tension, and torsion, for particular case of stress raiser.

Some other authors, [9], developed theoretical expressions for stress concentration factors for shoulder fillets in round and flat bars under various loads. But, the flat-plate fillet solution had not been translated into a $3 \mathrm{D}$ round shaft and can not cover all shaft designs today in use.

Modern analytical and numerical techniques can provide a more accurate, easier-to-handle solution. Many authors, [10], [11], used Finite Element Analysis (FEA) to overcome many of the inaccuracies of the previous method and previous Peterson's graphs. With the enormous rise in computing power, designers could use numerical equations to calculate SCF instead of relying on printed curves and tables. The authors form references [9] and [10] exploit the excellent knowledge of Finite Element Theory combined with separate design equation for each loading mode. The current question is whether it is better to calculate stresses for every external load separately, [11], or for complex loads at once, [5]? Different authors have different standpoints.

However, an important problem in shaft design is the determination of SCF at the shaft transition zone for shafts with flange and high ration of shaft radii/flange radii. These shafts are not covered with existing SCF graphs. The FEA is confirmed method for such problems, used for the calculation of stress concentration factors at transition zones, [12] and [13].

For SCF and maximum stress calculation of nonstandard shafts that required a high level of energy efficiency, and in the same time high level of reliability and safety, the procedure for calculations is not commonly defined in engineering practice, yet.

The stress concentration factor $K_{t}$ can be defined as the ratio of the peak stress in the body (or stress in the perturbed region) to some other stress (or stress like quantity) taken as a nominal stress:

$$
K_{t}=\frac{\sigma_{\max }}{\sigma_{\text {nom }}}
$$

In equation (1) the stress omax represent the maximum stress for actual loads and the nominal stress onom is reference normal stress. The subscript $t$ indicates that the stress concentration factor is a theoretical factor. In the case of the theory of elasticity, a two-dimensional stress distribution of a homogeneous elastic body under known loads is a function only of the body geometry and is not dependent on the material properties.

It is very important to properly identify the reference stress for the stress concentration factor of interest. Stress concentration factors can be obtained analytically from the elasticity theory, computationally from the Finite Element Method, and experimentally.

The recommended tabular value for the geometrical stress concentration factor for the described hollow shaft with flange at the shaft end in complex loading conditions doesn't exist. Therefore, described Finite Element Model is used for identification of nominal and maximum stresses for calculation of stress concentration factor of shaft-flange transition zone. Due to complex loading conditions, stress concentration factor has been calculated from the intensities of equivalent stresses, [12].

\section{SHAFT WITH FLANGE - A CASE STUDY}

In order to illustrate the methodology for shaft stress calculation, one particular shaft with flange is described and investigated in this paper. The selected shaft is a real horizontal hydro turbine shaft with significant radius change at transition zone from shaft to runner flange, which was the cause of failure. Figure 1 presents the detail of the hydro turbine shaft flange. The shaft material is steel 20GSL with main characteristics: Young modulus of elasticity $E=2.04 \cdot 10^{5} \mathrm{MPa}$; Poisson's rate $v=0.3$; yield strength $R_{e}=255 \mathrm{MPa}$; fatigue strength $\sigma_{D f(0)}=340 \mathrm{MPa}$ and $\sigma_{D f(-1)}=225 \mathrm{MPa}$, i.e. fatigue strength for 0 (one direction) and -1 (reversed) $\mathrm{min} / \mathrm{max}$ stress ratio $\mathrm{R}, \mathrm{GOST} 977$, [14] and [15]. Before the end of the guarantied working period, crack appeared on shaftflange radius, fig.1. Numerical Finite Element Method (FEM) is used during the failure investigation for critical zone stress calculation, as well as for determination of geometrical stress concentration factor, [15] and [16].

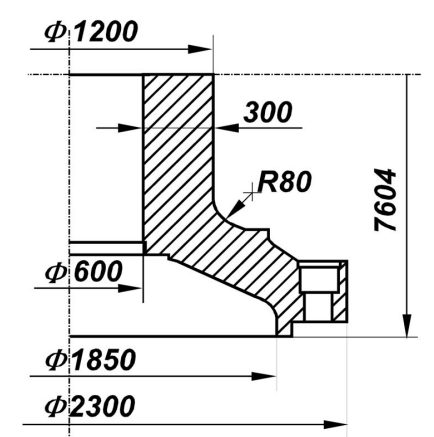

Figure 1. Shaft flange transition zone with $r=80 \mathrm{~mm}$

The original turbine shaft geometry with transition radius $r=80 \mathrm{~mm}$ in crack zone is simulated on the FEM model, fig.2. The ANSYS software for Finite Element Analysis (FEA) has been used for modeling the turbine 
shaft with one flange to generator shaft and another flange to runner, [13].

Figure 2 presents the 3D finite element model of analysed shaft with flange, made with continuum discretized by the 3D structural solid elements defined by 8 nodes that had three degrees of freedom at each node (translations in the nodal $\mathrm{x}, \mathrm{y}$ and $\mathrm{z}$ directions). The FEM model has 59120 nodes and 47547 elements. The boundary conditions and external loads are defined on FEM model as shown on fig.2: displacement constraints in radial direction ato nodes in contact with radial sliding bearing and fixed nodes which is interface with flange of generator shaft, [13].

The loads were taken from the original shaft manufacturer's documentation. The numerical calculations are performed for few load cases: regime during starting (LC1), regular operation regime (LC2), only bending from shaft's and runner's weight (LC3), only torsion from runner torque moment (LC4) and only tension from axial hydraulic force during starting regime (LC5), Table 1.

Table 1. Load cases in FEA analysis

\begin{tabular}{|c|c|c|c|c|}
\hline \multirow{2}{*}{$\begin{array}{c}\text { Load } \\
\text { case }\end{array}$} & \multicolumn{5}{|c|}{ Forces } \\
\cline { 2 - 5 } & Tension & Bending & Torsion & Pressure \\
\hline LC1 & $\mathrm{X}$ & $\mathrm{X}$ & $\mathrm{X}$ & $\mathrm{X}$ \\
\hline LC2 & $\mathrm{X}$ & $\mathrm{X}$ & $\mathrm{X}$ & \\
\hline LC3 & & $\mathrm{X}$ & & \\
\hline LC4 & & & $\mathrm{X}$ & \\
\hline LC5 & $\mathrm{X}$ & & & \\
\hline
\end{tabular}

Load case 1, Fig.2, corresponds to the static load during start of operation and change of the operating runner's blades position and it is defined by: the maximum axial hydraulic force of $F_{a}=5542.65 \cdot 10^{3} \mathrm{~N}$, pressure in servomotor $q=40$ bar, own shaft's weight, runner's weight of $G=1 \cdot 10^{6} \mathrm{~N}$ and the torque on the runner of $M_{t}=4280.5935 \cdot 10^{3} \mathrm{Nm}$. The total axial hydraulic force $F_{a}$ is simulated by the forces in axial direction (the $x$ axis direction) at points of connecting the shaft flange to the runner. The pressure in servomotor is simulated by surface pressure inside of the flange and axial force $F_{p}=p \cdot \pi\left(R^{2}-r^{2}\right)$, where the values of servomotor cylinder radius $R=925 \mathrm{~mm}$ and servomotor toggle radius $r=190 \mathrm{~mm}$ were taken over from the original turbine manufacturer's documentation. The shaft's own weight was simulated by gravitational acceleration. The runner's weight was reduced to the

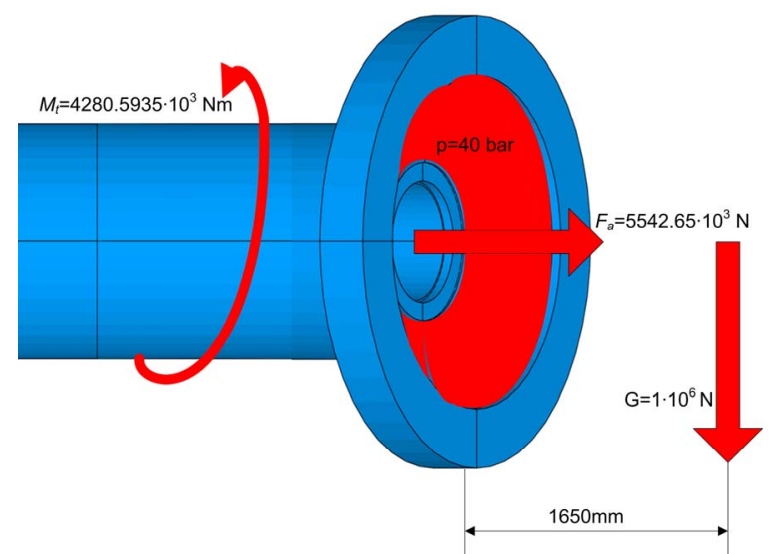

points of connecting the flange with runner. The torque was simulated by the forces in radial direction in all the nodes at the shaft flange perimeter, so that the total torsion moment from these forces represents the torque, while the bending moments of these forces as well as the forces themselves are mutually cancelled.

Load case 2 corresponds to the dynamic, time-variable load in the course of normal operating regime and it is defined by: axial hydraulic force of $F_{a}=392.4 \cdot 10^{3} \mathrm{~N}$, own shaft's weight, runner's weight of $G=1 \cdot 10^{6} \mathrm{~N}$ and the torque on the runner of $M_{t}=4280.5935 \cdot 10^{3} \mathrm{Nm}$, defined in the same way as for load case 1.

The Finite Element Analysis (FEA) of analysed turbine shaft was performed for all defined load cases. The obtained numerical results for stress states in transition zone are presented on fig. 3 and fig. 4 in form of contour plots for equivalent stresses $\sigma_{\text {eqv }}$, calculated according to the von Mises's criterion. Figure 3 shows the $\sigma_{e q v}$ in shaft-flange transition zone for load case 1 (regime during starting). From the stress contours display nominal stress $\sigma_{\text {eqv-nom }}=32$ $\mathrm{MPa}$ and maximum stress $\sigma_{\text {eqv-max }}=127 \mathrm{MPa}$ can be read at the transition radius that corresponds to the real crack initiation location. For regular operation regime (load case 2), nominal stress $\sigma_{\text {eqv-nom }}=28 \mathrm{MPa}$ and maximum stress $\sigma_{\text {eqv-max }}=57.6 \mathrm{MPa}$ can be read from numerical results, fig.4. Likewise, nominal and maximum stresses can be read for all other load cases.

The figure 3 also shows the nominal and maximum stresses for component loading cases which make regime during starting loading: bending, torsion and tension.

The obtained values of nominal and maximum stresses for all load cases are given in tables 1 and 2 .

\section{INFLUENCE OF TRANSITION RADIUS ON SCF}

The described non-standard shaft with flange is part of hydro turbine. The maximum equivalent stresses in critical shaft/flange transition zone obtained by FEA and presented in previous chapter don't exceed fatigue strength of $\sigma_{D f(0)}=340 \mathrm{MPa}$, [13], for load regime during starting turbine (maximum static load), as well as fatigue strength of $\sigma_{D f(-1)}=225 \mathrm{MPa}$, [13], for regular operation regime (dynamic cycling loading).

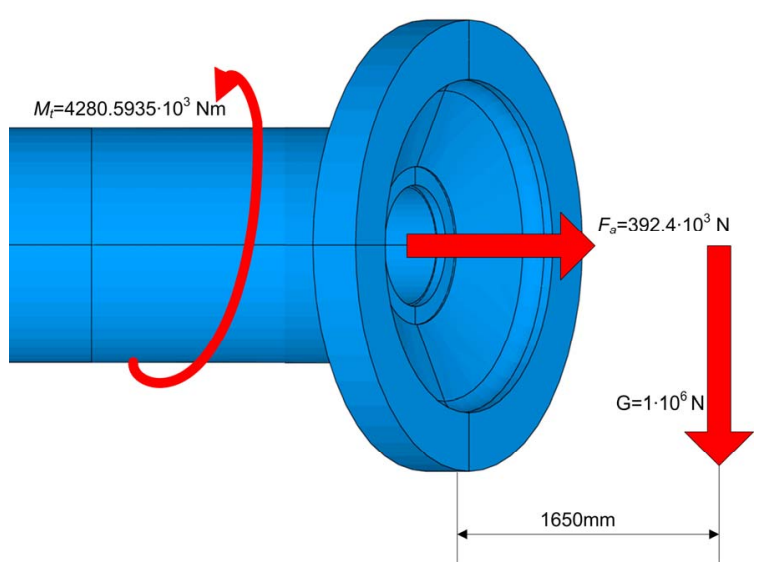

Figure 2. Combined loading in FEA for regime during starting and normal operating regime 
But, because the failure occurred, the research of shaft-flange transition section influence on stress concentration factor has been performed. The stress concentration factor values are calculated for variable transition radius $r$. For these purposes, the numerical calculations were performed for real shaft transition radius $r=80 \mathrm{~mm}$ and also for radii of $70 \mathrm{~mm}, 100 \mathrm{~mm}$ and $120 \mathrm{~mm}$. The obtained results have been used for SCF estimations and comparison.

The calculations of the nominal and maximum stresses for real transition radius $(80 \mathrm{~mm})$ of real hydro turbine hollow shaft with flange are performed for 5 defined load cases. The similar Finite Element Models and Finite Element Analysis are performed for each of the chosen variable radius values. Fig.5 gives transition zone display with variable radii. The obtained numerical results are presented in Table 1 for maximum von Mises's stresses and in Table 2 for calculated SCF.

The analysis of SCF for all analysed load cases for different transition radii shows the reduction of maximum stresses and SCF with radii increasing, which is expected conclusion, [11].

The Fig.6 shows the graph of SCF versus $r / d$ ( $r$-transition shaft/flange radius, $d$-shaft diameter) for combined start load (load case 1). At the same way, the Fig.7 shows the graph of SCF versus $r / d$ for complex load during regular operation regime (load case 2) and Fig.8 shows the graphs of SCF versus $r / d$ for component loads: bending, tension and torsion

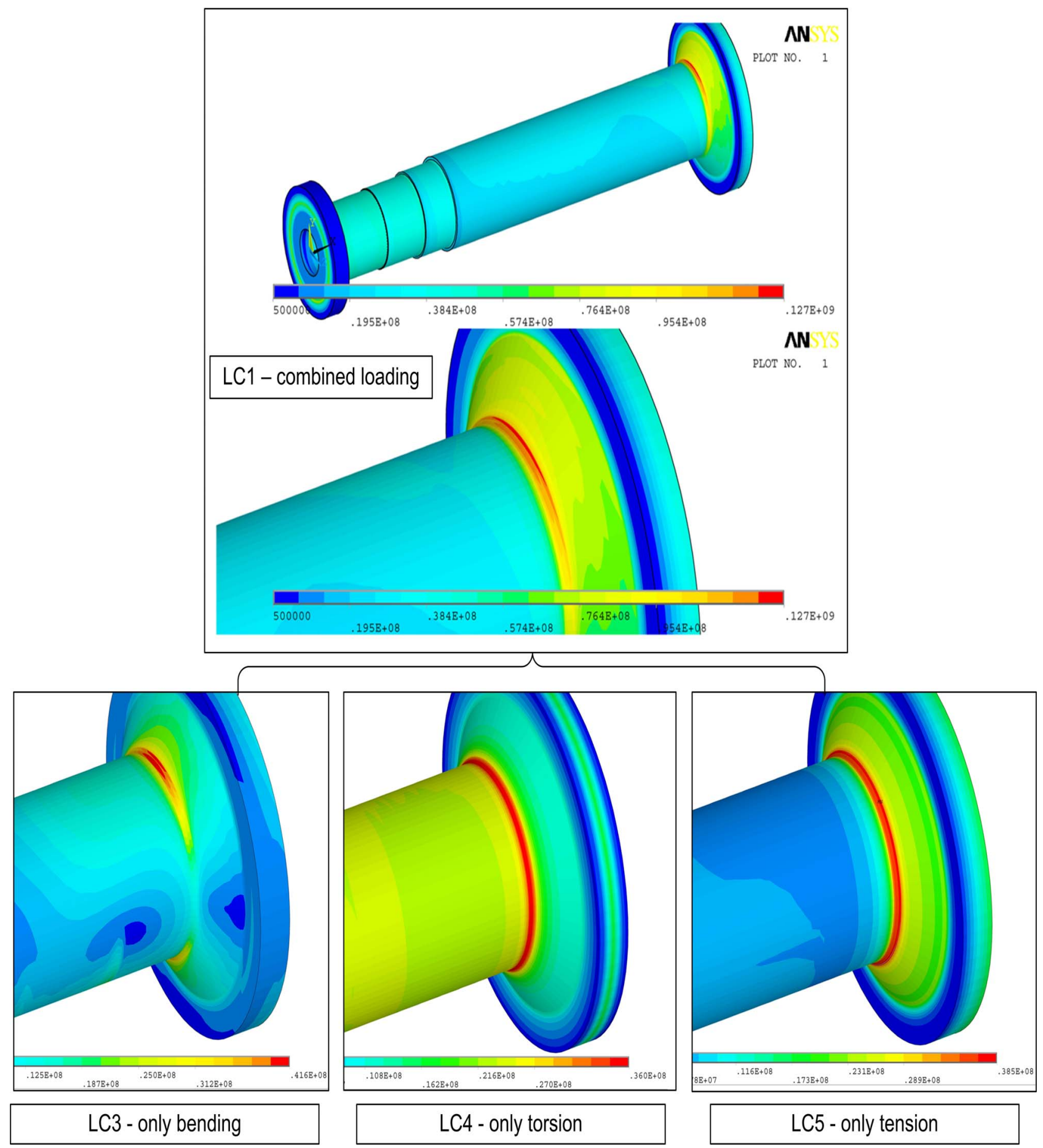

Figure 3. VM equivalent stresses during starting (LC 1) and for component, $r=80 \mathrm{~mm}$ ), $\mathrm{Pa}$ 


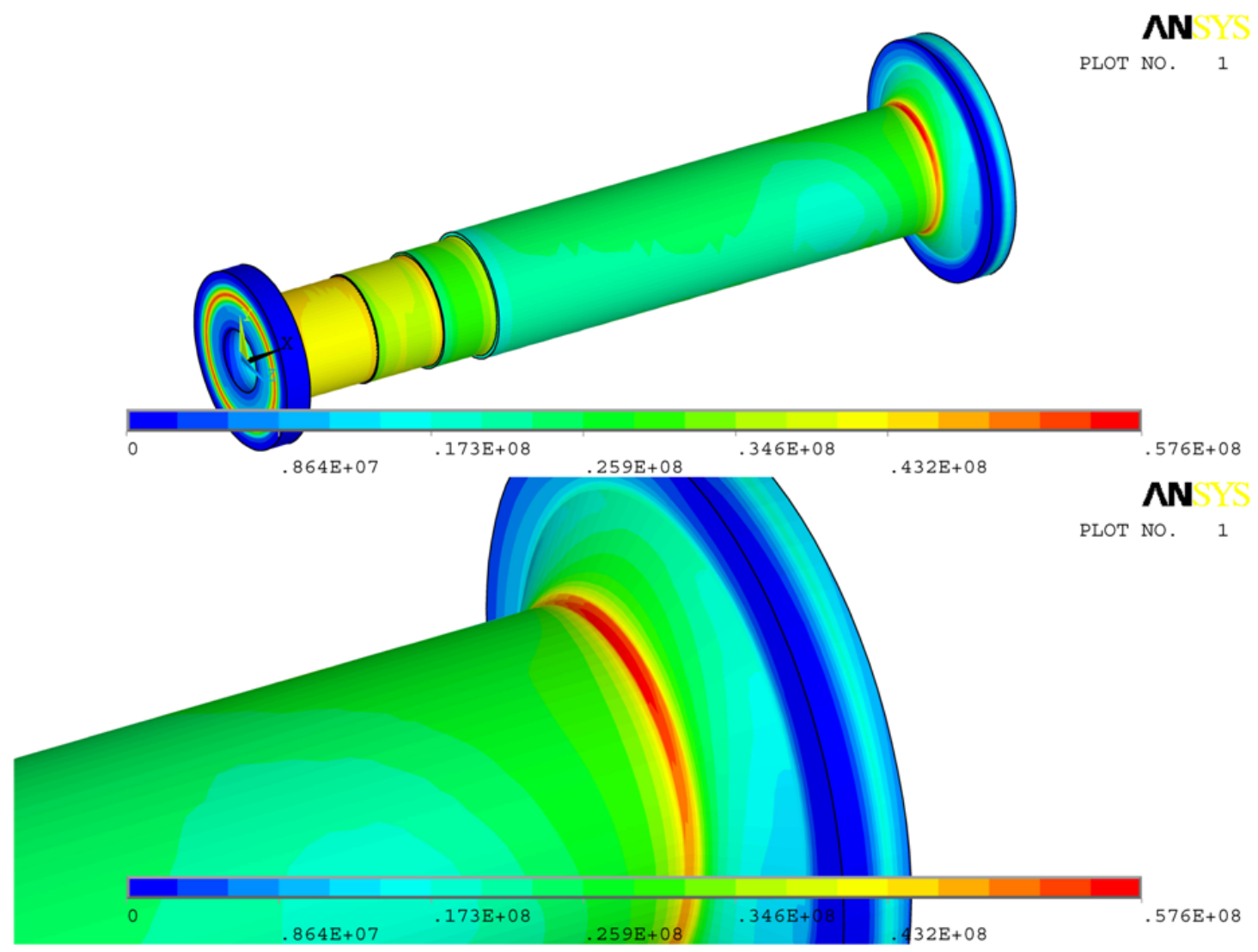

Figure 4. VM equivalent stresses for regular operation (LC2), Pa

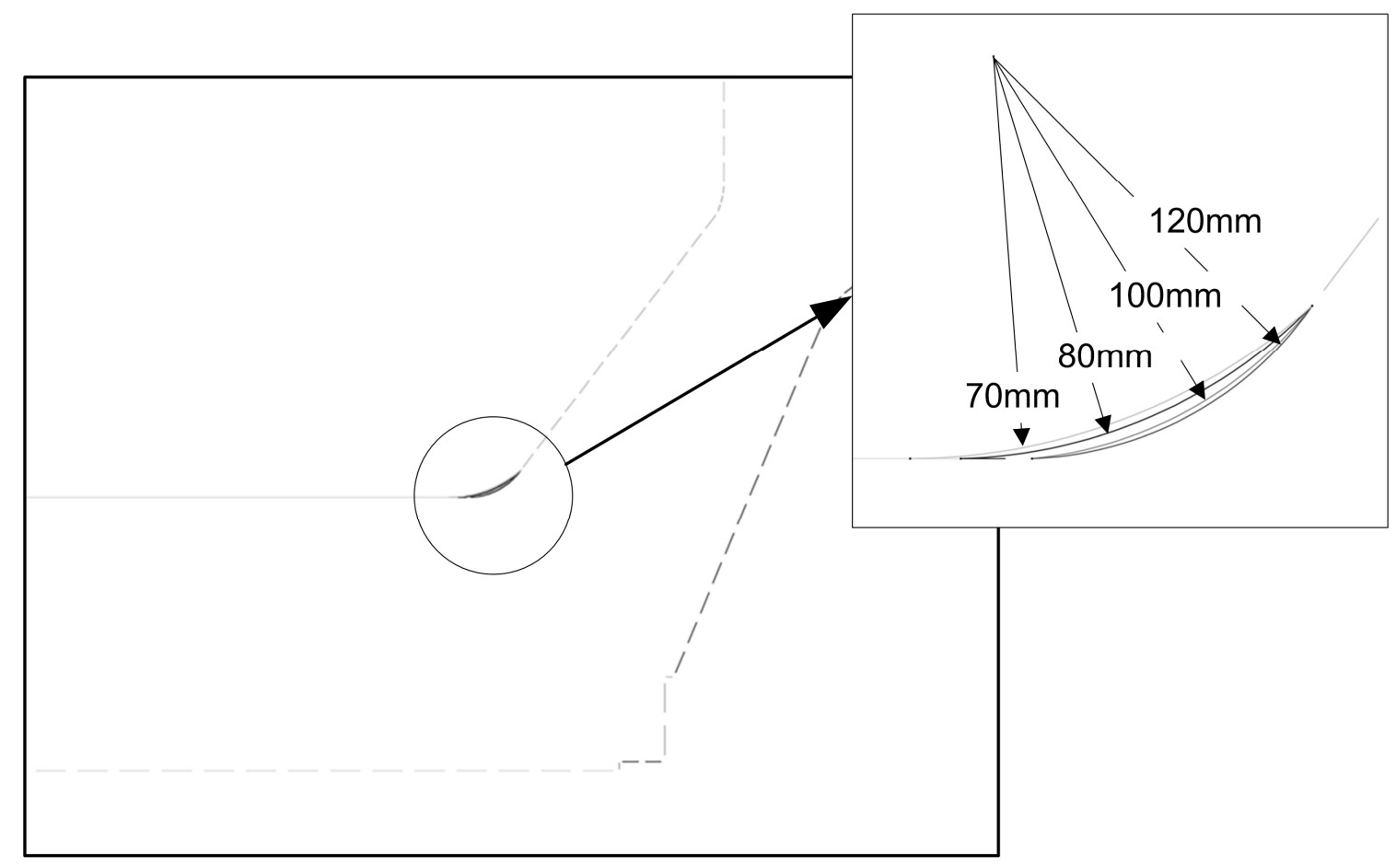

Figure 5. Transition zone with different values of shaft to flange radius

Table 1: Maximum von Mises's stresses for different load cases

\begin{tabular}{|c|c|c|c|c|c|c|}
\hline$r(\mathrm{~mm})$ & $r / d(\mathrm{~mm})$ & $\begin{array}{c}\sigma_{\text {eqvLCl }} \\
(\mathrm{MPa})\end{array}$ & $\begin{array}{c}\sigma_{\text {eqvLC2 }} \\
(\mathrm{MPa})\end{array}$ & $\begin{array}{c}\sigma_{\text {eqvLC3 }} \\
(\mathrm{MPa})\end{array}$ & $\begin{array}{c}\sigma_{\text {eqvLC4 }} \\
(\mathrm{MPa})\end{array}$ & $\begin{array}{c}\sigma_{\text {eqvLC5 }} \\
(\mathrm{MPa})\end{array}$ \\
\hline 70 & 0.05833 & 136 & 58.8 & 44.8 & 36.2 & 41.5 \\
\hline 80 & 0.06667 & 127 & 57.6 & 41.6 & 35.5 & 38.5 \\
\hline 100 & 0.08333 & 122 & 54.9 & 41.4 & 33.8 & 37.4 \\
\hline 120 & 0.1 & 120 & 52.1 & 39.2 & 32.6 & 36.5 \\
\hline
\end{tabular}


Table 2: Stress concentration factors for different load cases

\begin{tabular}{|c|c|c|c|c|c|c|}
\hline$r(\mathrm{~mm})$ & $r / d(\mathrm{~mm})$ & $K_{t L C l}(/)$ & $K_{t L C 2}(/)$ & $K_{t L C 3}(/)$ & $K_{t L C 4}(/)$ & $K_{t L C 5}(/)$ \\
\hline 70 & 0.05833 & 4.25 & 2.1 & 2.97 & 1.54 & 8.3 \\
\hline 80 & 0.06667 & 3.97 & 2.057 & 2.75 & 1.52 & 7.7 \\
\hline 100 & 0.08333 & 3.8125 & 1.961 & 2.74 & 1.44 & 7.48 \\
\hline 120 & 0.1 & 3.75 & 1.861 & 2.6 & 1.393 & 7.3 \\
\hline
\end{tabular}

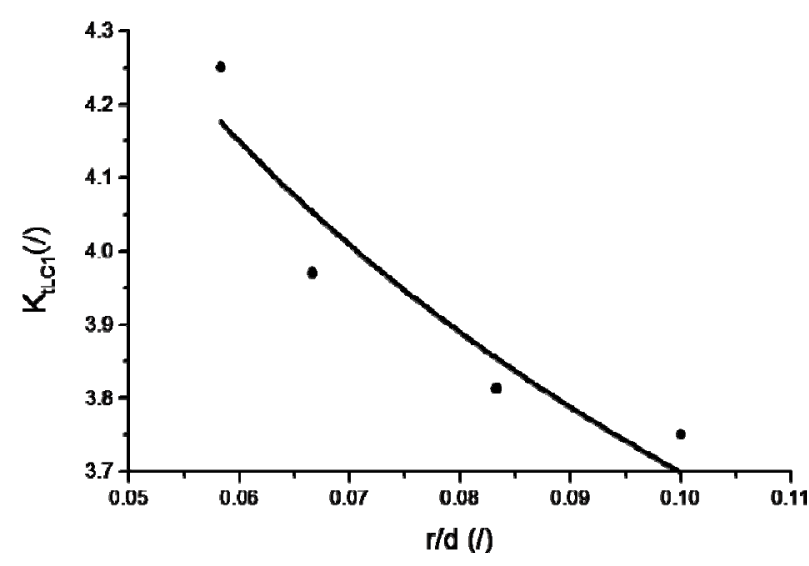

Figure 6. SCF for regime during starting

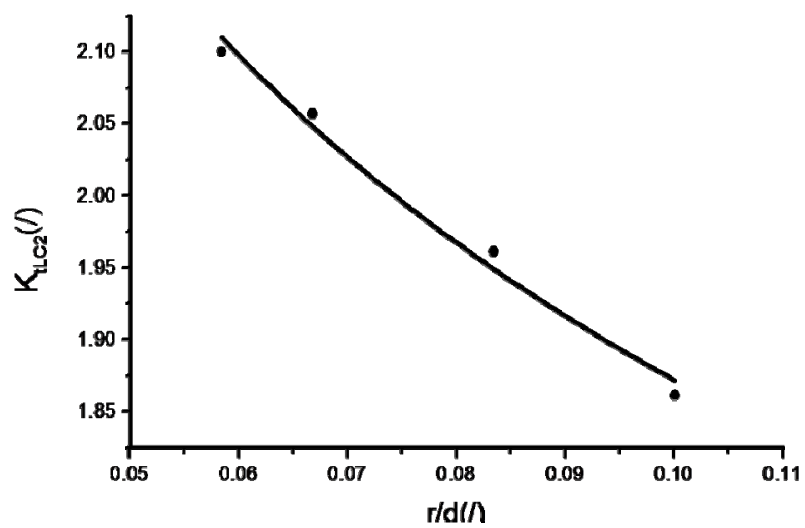

Figure 7. SCF for regular operation regime

These graphs can be described with function:

$$
K_{t}=f(r / d)=a\left(\frac{r}{d}\right)^{-b}
$$

where $a$ and $b$ are constants. For investigated shaft with flange calculation by numerical method of least square gives the constants given in table 3 . The selected function described $K_{t}$ as function of $r / d$ with minimum deflections. These expressions' form, given with equation (2), is in accordance with the expressions obtained from the authors in [11] for another hollow shaft with flange.

Table 3: Stress concentration factor function constants for different load cases

\begin{tabular}{|l|c|c|c|c|c|}
\hline & $K_{t L C l}(/)$ & $K_{t L C 2}(/)$ & $K_{t L C 3}(/)$ & $K_{t L C 4}(/)$ & $K_{t L C 5}(/)$ \\
\hline$a$ & 2.20146 & 1.1212 & 1.59172 & 0.89047 & 4.32015 \\
\hline$b$ & 0.22536 & 0.00052 & 0.21331 & 0.19454 & 0.22297 \\
\hline
\end{tabular}
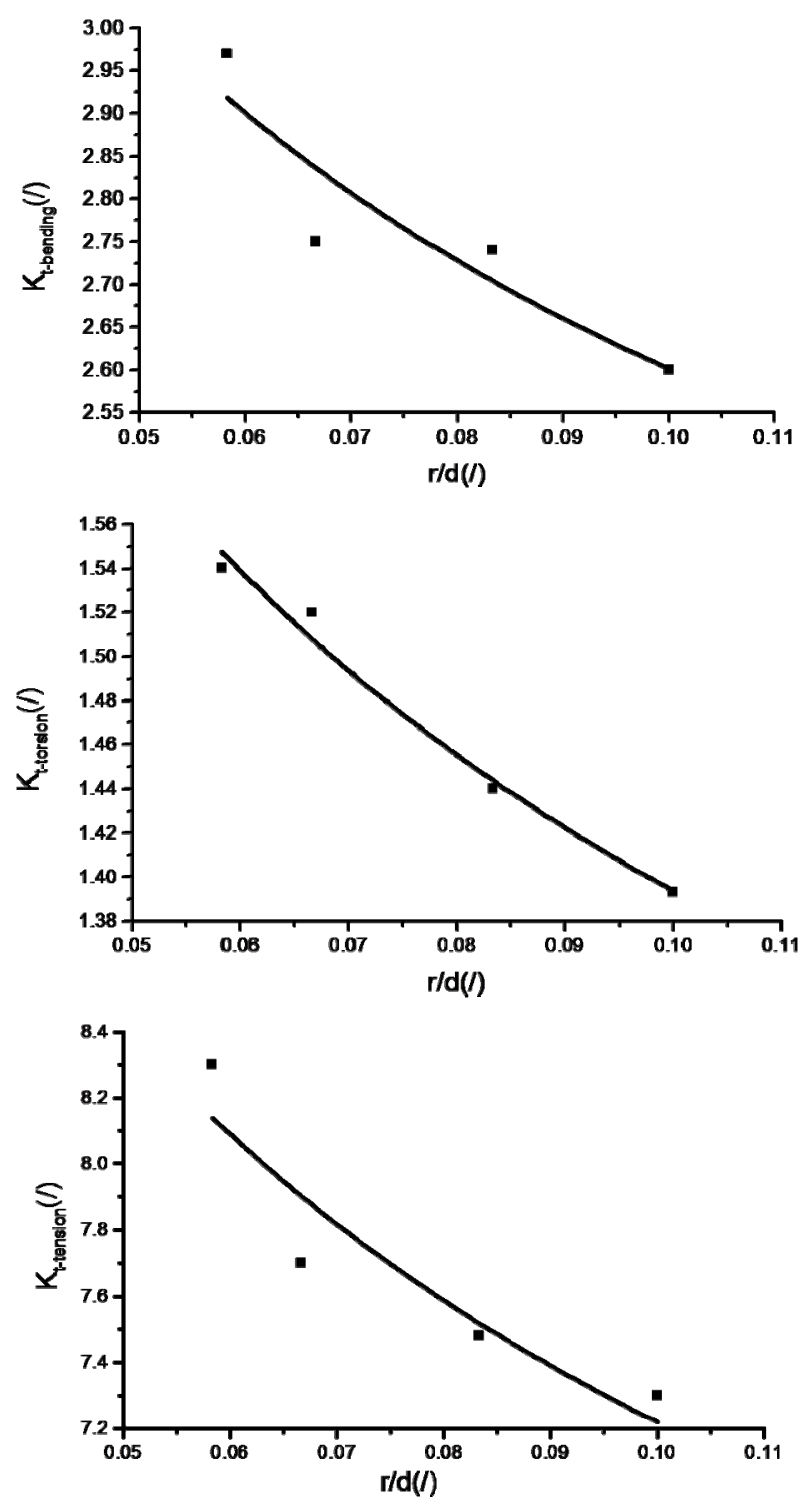

Figure 8. SCF for bending, torsion and tension

\section{COMBINED LOAD SIMULATION VS COMPONENT LOADS SIMULATION}

The comparative graphical presentation of results is the most illustrative method for making the comparison and analysis of results obtained by Finite Element Analysis (FEA) and analytical calculation with Peterson's SCF. Graph on fig. 9 shows the comparison of results for SCF obtained by FEA with analytical calculation of total stress by simulating load cases of only bending and only torsion, and results for SCF obtained by FEA by 
simulation bending and torsion simultaneously. The hypothesis of maximum normal stress is used for the total stress calculation, [12].

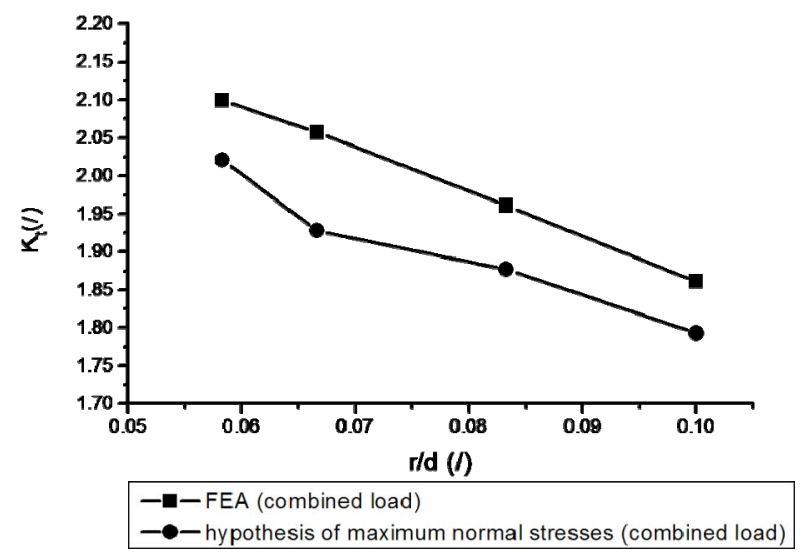

Figure 9. Comparative review of SCF obtained with FEA and simulation of combined load, and with FEA and simulation of component loads

One more question that is raised after the analysis presented in this paper is - what is better: to calculate stress concentration factors for different stress components of complex load and then calculate analytical values of total stress, or simulate all external loads on real machine part FEM model and perform numerical calculation of total stress. The answer is easy to find by analyse of comparative graph shown on fig.9 and fig.10: Finite Element Analysis of a machine part with non-standard transition zone geometry gives stress state calculation that can not be replaced with standard analytical calculations.

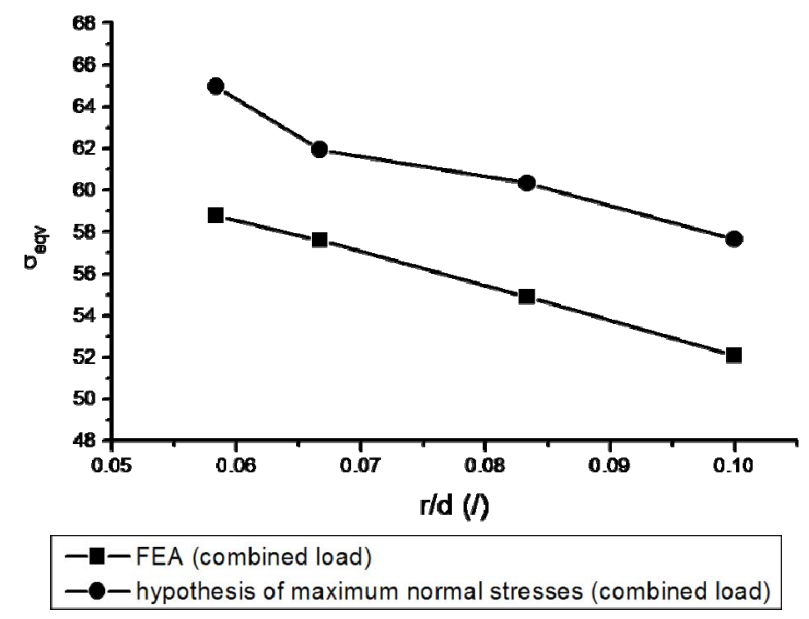

Figure 10. Comparative review of stresses obtained with FEA and simulation of combined load, and with FEA and simulation of component loads

\section{CONCLUSION}

The presented approach for determination of the stress concentration factor in transition section of shaft with flange and calculation of maximum stresses at transition zones by FEA should leads to more accurate calculation results of non-standard shafts. Finite Element Analysis of a machine part with non-standard transition zone geometry can not be replaced with standard analytical calculations. This is supported by the fact that shaft had premature failure although analytical calculation results show that load capacity is in accordance with working load conditions. For every particular machine part (shaft, gear, bearing), engineers have to make decision whether to calculate it by FEA or by standard analytical method. The decision must take into account the required energy efficiency, as well as required reliability and safety level of the machine part. The descried methodology is reliable, but time cost at the same time, so it is suitable for shaft with the flanges and non-standard geometry when they have special durability requirements, such as shafts at excavators, turbines and other parts in heavy machinery.

This paper is a confirmation that the use of Peterson's SCF and standard analytical techniques for total stress calculation has to be replaced by modern calculation techniques that provide a more accurate, easier-to-handle solution and overcome many of the inaccuracies of the previous method. This statement is particularly valid for multiaxial stresses around geometry features that induce local rise of stresses. Further development of this methodology can be applied to SCF within SCF such as corrosion pit on various stress concentration features [17] and [18].

The analysis of these diagrams leads to the conclusion that simulation of all external loads on a real machine part FEM model and performing numerical calculation of total stress by single calculation is much more accurate than calculations of stress concentration factors for different stress components of a complex load and following the calculation of analytical values of total stress.

\section{ACKNOWLEDGMENT}

This research were supported by the Ministry of Sciences and Technology of Republic of Serbia, Grant TR 35029 Development of the methodology for working capacity, reliability and energy efficiency improvement of energetic mechanical systems.

\section{REFERENCES}

[1] Tinga, T: Principles of Loads and Failure Mechanisms Applications in Maintenance, Reliability and Design, Springer Series in Reliability Engineering - Springer, pp 92-96, 2013

[2] Bakić, G., Đukić M., Lazović T., Prokić Cvetković, R., Popović, O. and Rajičić, B.: New methodology for monitoring and prevention of rotating parts failures, FME Transactions, Vol. 35, No 4, pp.195200, 2007.

[3] Krupp, U.: Fatigue Crack Propagation in Metals and Alloys, WILEY-VCH Verlag GmbH \& Co. KgaA, pp1-2, 2007

[4] Bachschmid, N., Pennacchi, P. and Tanzi, E.: Cracked Rotors - A Survey on Static and Dynamic Behaviour Including Modelling and Diagnosis, Springer, pp 1-13, 2010

[5] Vullo, V. and Vivio, F.: Rotors: Stress Analysis and Design, Mechanical Engineering Series - Springer, pp 205, 2013

[6] Ishida, Y.: Cracked rotors: industrial machine case histories and nonlinear effects shown by simple 
jeffcott rotor, Mechanical Systems and Signal Processing, Vol. 22, No. 4, pp. 805-817, 2008

[7] Noda, N.A., Takase, Y. and Monda, K.: Stress concentration factors for shoulder fillets in round and flat bars under various loads, International Journal of Fatigue, Vol.19, No. 1, pp 75-84, 1997.

[8] Pilkey, W.D. and Pilkey, D.F.: Peterson's Stress Concentration Factors, John Wiley \& Sons, Inc., 2008.

[9] Shapiro, J.: Streamlining shoulder-fillet stresses, Machine Design.com, pp 84-86, 2009.

[10] Tipton, S.M., Sorem, J.R. and Rolovic, R.D.: Updated stress concentration factors for filleted shafts in bending and tension, Journal of Mechanical Design, Transactions of the ASME, Vol. 118, pp 321-327, 1997.

[11] Djordjevic, Z., Nikolic, V. and Atanasovska, I.: Finite Element Analysis of deformation and stress state of hollow shaft, IX Simposium MVM, Kragujevac, Serbia, pp 156-159, 1996.

[12] Nikolić, V.: Mechanical analysis of elements of gear trains, University of Kragujevac, 1999., (in Serbian)

[13] Atanasovska, I., Mitrović, R. and Momčilović, D.: FEM model for calculation of Hydro turbine shaft, in: Proceedings - the Sixth International Symposium KOD 2010, Palić, Serbia, pp 183-188, 2010.

[14]GOST 977-88, Steel castings. General specifications, 1988.

[15] Atanasovska, I, Mitrović, R and Momčilović, D: Influence of transition section of shaft with flange on stress concentration factor, in: Proceedings of the 7th International scientific conference Research and development of mechanical elements and systems, 27-28. of april, 2011., Zlatibor, Serbia, Publisher: Mechanical Engineering Faculty, Niš, Serbia, Topic: Safety, Quality and Reliability, pp. 213-218, 2011.

[16] Momčilović, D., Odanović, Z., Mitrović, R., Atanasovska I., and Vuherer, T.: Failure Analysis of Hydraulic Turbine Shaft, Engineering Failure Analysis, Published by Elsevier, Volume 20, pp. 54-66. 2012.

[17] Mitrović, R., Momčilović, D. and Atanasovska, I.: Assessment of the Effect of Pitting Corrosion on Fatigue Crack Initiation in Hydro Turbine Shaft, Advanced Materials Research, ISSN: 1022-6680, Vol. 633: Advances in Engineering Materials, Product and Systems Design (Special topic volume with invited peer reviewed papers only), Trans Tech Publications, Switzerland, pp. 186-196, 2013.
[18] Momčilović, D., Mitrović, R., Atanasovska I. and Vuherer, T.: Methodology for determination the influence of corrosion pit on decrease of hydro turbine shaft fatigue life, Journal Machine Design, Vol. 4, No.4, pp. 231-236, 2012.

\section{УПОРЕДНА АНАЛИЗА ПРОРАЧУНА МАШИНСКИХ ЕЛЕМЕНАТА СИМУЛИРАЊЕМ КОМБИНОВАНОГ ОПТЕРЕТЕЊА И ОДВОЈЕНИМ СИМУЛИРАҢЕМ КОМПОНЕНТНИХ ОПТЕРЕЪЕЊА - СТУДИЈА СЛУЧАЈА}

\section{Д. Момчиловић, А. Субић, И. Атанасовска, Р. Митровић}

На садашњем нивоу развоја технологије, у стварним радним условима, готово сви машински елементи су оптерећени комбинованим оптерећењима. Циљ истраживања приказаног у овом раду је указивање на значај прорачуна носивости машинских елемената симулирањем комбинованог оптерећења. Истраживање приказано у раду инспирисано је једним стварним отказом турбинског вратила хидротурбине. Вратило са прирубницом и високим односом пречника вратила и прирубнице било је предмет обимних прорачуна у циљу проналажења узрока отказа.

Класични аналитички прорачун овог вратила користи Peterson-ов фактор концентрације напона и прорачун максималних напона за поједине напонске компоненете комбинованог оптерећења, а онда аналитичку вредност укупног напона прорачунава на основу хипотезе о максималном нормалном напону. Са друге стране, приказани прорачун напонског стања вратила методом коначних елемената базира се на симулирању реалних радних оптерећења у условима комбинованог оптерећења истовременим дефинисањем свих компоненти (савијања, увијања и затезања). Оба прорачуна урађена су за неколико различитих радијуса на прелазу вратила ка прирубници.

Добијени резултати приказани су упоредним дијаграмима добијених вредности укупних напона и одговарајућих фактора концентрације напона. Анализа ових дијаграма води до закључка да прорачун укупног напона у случају комбинованог и сложеног оптерећења на бази Peterson-ових фактора концентрације напона и стандардног аналитичког поступка треба да буде замењен напредним техникама прорачуна који обезбеђују тачнија решења која се истовремено и једноставније анализирају и користе. 